\title{
SOVEREIGN DEBT RESTRUCTURING: STATUTORY REFORM OR CONTRACTUAL SOLUTION?
}

\author{
JONATHAN SEDLAK ${ }^{\dagger}$
}

\section{INTRODUCTION}

During the last twenty years, as the global financial markets have become increasingly interdependent, the problem of sovereign debt has become more pronounced. Simultaneously, irresponsible lending practices and unwise investment strategies have led to several wellpublicized financial "crises." A solution is needed to improve the efficiency of the international financial market, to encourage wiser investment, and to offer a method of market stabilization when events reduce the likelihood of sovereign debt repayment. This Comment addresses whether that solution can be provided through private negotiation or whether a new, intergovernmental structure must be effected.

The problem of sovereign debt has been the subject of significant academic debate.' Indeed, two competing proposals for dealing with the restructuring of sovereign debt recently have come to the fore.

${ }^{\dagger}$ B.A. 1999, La Salle University; J.D. Candidate 2004, University of Pennsylvania. I owe a debt of gratitude to Professor David Skeel for his assistance in developing this Comment. I would like to thank Christina Anderson, Ilana Eisenstein, and Rob Ballenger for their insightful remarks and editing expertise. This Comment would not have been possible without the years of love and support from my family. Thank you for everything. Finally, I would like to thank Sarah for her incredible patience, support, and encouragement over the last three years. This Comment is dedicated to the memory of Catherine Ghiazza. All errors contained herein are my own.

${ }^{1}$ Compare Kenneth Rogoff \& Jeromin Zettelmeyer, Bankruptcy Procedures for Sovereigns: A History of Ideas, 1976-2001, 49 IMF STAFF PAPERS 470 (2002) (providing an outline of the intellectual predecessors to the sovereign debt restructuring mechanism (SDRM) proposal placed within the purview of bankruptcy law during 2001), available at http://www.imf.org/external/pubs/ft/staffp/2002/03/pdf/rogoff.pdf, and Steven L. Schwarcz, Sovereign Debt Restructuring: A Bankruptcy Reorganization Approach, 85 CORNELL. L. REV. 956, 1030-31 (2000) (developing the idea of an intergovernmental bankruptcy procedure), with Lee C. Buchheit \& G. Mitu Gulati, Sovereign Bonds and the Collective Will, 51 EMORY L.J. 1317, 1358 n.87 (listing sources that support collective action clauses), and BARRY EICHENGREEN \& ASHOKA MODY, WOULD COLLECTIVE ACTION Clauses RAISE BorRowING COSTS? 22-23 (Nat'l Bureau of Econ. Research, Working Paper No. 7458, 2000) (characterizing collective action clauses as beneficial), available at http://papers.nber.org/papers/w7458.pdf. 
One proposal, advocated by the U.S. Treasury Department, encourages lenders to include collective action clauses in their debt instruments as a method of dealing with potential debt restructuring. ${ }^{2}$ The other position, advocated by some at the International Monetary Fund (IMF) (particularly fund director, Anne Krueger), suggests that market participants adopt a statutory scheme to deal with the problem. ${ }^{3}$ This statutory scheme has been labeled the sovereign debt restructuring mechanism (SDRM).

While both proposals had their share of supporters and detractors, the IMF's SDRM received a substantial blow during the fund's spring meeting of 2003. During this meeting, Treasury Secretary John Snow cited market moves toward collective action clauses and concluded that it was "neither necessary nor feasible to continue working on SDRM." Such a position by the United States, the largest contributor to the IMF, makes it difficult, if not impossible, to implement anything like the SDRM. ${ }^{6}$ In fact, this pronouncement by Secretary Snow has caused at least one source to declare that the SDRM is "officially dead." Although these developments significantly impair the likelihood of implementing anything that resembles the SDRM in the near future, the inherent flaws of a market-based approach coupled with the growing recognition of the need for a more systematic process indicate that we are at the beginning, not at the end, of this debate.

This Comment focuses the debate over these two proposed solutions to the sovereign debt crisis. Its purpose is to identify the theory underlying these competing solutions. Bankruptcy law is not a monolithic legal theory. Rather, it encompasses societal values concerning who should bear the financial loss that inevitably results from insolvency. The ensuing discussion rests on the premise that a better

${ }^{2}$ See infra Part III (describing the Treasury Department's market-based approach).

${ }^{3}$ See infra Part II (describing the IMF's innovative approach).

4 Anne Krueger, International Financial Architecture for 2002: A New Approach to Sovereign Debt Restructuring, Address Before the National Economists' Club Annual Members' Dinner (Nov. 26, 2001), available at http://www.imf.org/external/np/ speeches/2001/112601.htm.

${ }^{5}$ John W. Snow, Statement at the Meeting of the International Monetary and Financial Committee (Apr. 12, 2003), available at http://www.imf.org/external/spring/ 2003/imfc/state/eng/usa.htm.

${ }^{6}$ See Dan Taylor, The International Monetary Fund: Wallet Sore to the West or Savior to the Global Financial Crisis, 8 CURRENTS: INT'L TRADE L.J. 79 (1999) (recognizing that the United States has more voting power than any other member nation because it is the largest contributor to the IMF).

${ }^{7}$ SDRM Is Dead, and That's Official, EUROMONEY, May 2003, at 102, 102. 
evaluation of the competing proposals for dealing with sovereign debt can be achieved by examining them in the context of bankruptcy theory.

This Comment addresses the problem as follows: Part I gives an overview of sovereign debt and examines the historical methods for dealing with financial crises when a sovereign defaults on its loans. Part II explores a recent statutory proposal advanced by the IMF, which is designed to create the functional equivalent of an international bankruptcy court. Part III examines an alternative, marketbased approach to dealing with sovereign debt that is currently advocated by the U.S. Treasury Department. Part IV considers the competing axioms present in bankruptcy law generally while Part $\mathrm{V}$ analyzes both the statutory and market-based approaches for evidence of the tensions present in modern bankruptcy theory. Part VI concludes by recommending a traditionalist-based approach to solving the sovereign debt crisis. This conclusion results from the unique nature of sovereign debt explored in some detail here and in the concerns addressed by the SDRM, but ignored by the Treasury Department proposal.

\section{Restructuring SOVEREIGN DeBT}

\section{A. History of Sovereign Debt}

Sovereign debt can be defined as the "debt incurred by governments, typically those of developing countries, to foreign investors seeking a competitive return." Notably, this definition excludes several other types of financing available in the international financial market such as government debt to public institutions, private borrowing in international capital markets, and direct foreign investment. ${ }^{9}$

A good starting point for the analysis of sovereign debt is an inquiry into why an independent country, with internal sources of financing, would need to borrow money from foreigners. First, no country has an inexhaustible supply of resources available for investment. Countries face the same economic choices confronting

8 Jonathan EATON \& RaQuel FERnANdez, SOvereign Debt 1 (Nat'l Bureau of Econ. Research, Working Paper No. 5131, 1995), available at http://www.nber.org/ papers/w5131.pdf.

${ }^{9}$ Id. at 1 n.2. These forms of financing are typically excluded from a discussion of sovereign debt restructuring because each of them has its own enforcement mechanisms and does not suffer from the unique problems associated with sovereign debt. See infra Part I.B (describing the signature attributes of sovereign debt). 
individuals and corporations in a world of scarcity. A country must decide how much of its resource supply to consume and how much of its resource supply to invest in the hope of increasing future consumption. At the same time, the level of current consumption necessarily constrains the resources available for investment. Borrowing, therefore, allows a country to increase the resources available for investment without having to forgo current consumption. A country can borrow capital for investment, and as long as the value of the goods produced by that capital exceeds the cost of acquiring external capital, it is in the country's long-term economic interest to do so. ${ }^{10}$

Mirroring the incentives for countries to borrow are the incentives for creditors to lend. These incentives are typically divided into factors that are external and those that are internal or specific to the borrowing country. ${ }^{11}$ External factors include lower average interest rates, economic slowdowns in more developed countries (a factor that limits investment opportunities in those markets), and a growing trend among all investors toward diversification of investments through international markets. ${ }^{12}$ Internal factors include the adoption of sound monetary and fiscal policies by some developing countries and active promotion of improved debtor/creditor relationships. ${ }^{13}$ The incentives for creditors to lend and for debtors to borrow together create the market for sovereign debt.

${ }^{10}$ See Gunter Dufey, Comporate Debt vs. Country Debt: Distinguishing Between Liquidity and Solvency Problems, in PRIVATE Sector SOlutions to THE LATIN AMERICAN DebT PROBLEM 35, 37 (Robert Grosse ed,, 1992) (justifying long-term borrowing for sovereign nations "whenever the additional goods and services created by the additional investment exceed the (risk-adjusted) cost of external funds"). At this point, the considerations for countries are remarkably similar to the investment considerations for a corporation. A corporation borrows money to finance projects that have positive net present values. See generally Richard A. BREAley \& STUART C. MYERS, PRINCIPLES OF CORPORATE FINANCE 18-22 (7th ed. 2003) (explaining that, in making an investment decision, investors, on a general level, and corporations, more specifically, often aspire to follow the "net present value rule" by investing in a project with positive net present value).

See Guillermo A. Calvo et al., Inflows of Capital to Developing Countries in the 1990s, J. ECON. PERSP., Spring 1996, at 123, 125-28 (1996) (listing and briefly describing the factors involved in investment decisions affecting the inflow of capital into the developing countries of Latin America and Asia).

\footnotetext{
${ }^{12}$ Id. at $126-27$.

${ }^{13} \mathrm{Id}$. at 127-28.
} 


\section{B. The Unique Aspects of Sovereign Debt}

With the above understanding of sovereign debt in mind, I now consider the unique problems that arise when a country is unable or refuses to pay its debts. A vast literature (comprised of mostly economists' contributions) devotes itself to the deceptively simple question of why a country repays its debts. ${ }^{14}$ An examination of all the proposed conclusions in that literature is beyond the scope of this Comment. However, the inquiry highlights major distinctions between sovereign debt and corporate debt. Ultimately, three characteristics distinguish the two types of debt.

First, at least in an abstract sense, a country can always service its debt, which makes it difficult to determine if a country is ever "insolvent." A company repays its debts because it must. If a company fails to repay its debts, the business can be dismantled by the unpaid creditors. $^{15}$ However, no parallel mechanism exists to force repayment by sovereign nations since no creditor has the ability to dismantle or liquidate a country. As a result, collection remedies against countries remain extraordinarily complex and difficult to execute.

Furthermore, a corporation's ability to service its debt ${ }^{16}$ is undoubtedly a methodical question, based primarily on the value of the

${ }^{14}$ See Jonathan Eaton \& Mark Gersovitz, Debt with Potential Repudiation: Theoretical and Empirical Analysis, 48 REV. ECON. STUD. 289, 289-90 (1981) (proposing a reputational model to describe why countries repay debt). But see Jeremy Bulow \& Kenneth Rogoff, A Constant Recontracting Model of Sovereign Debt, 97 J. POL. ECON. 155, 157-58 (1989) (noting some of the reputational model's limitations).

${ }_{15}$ "Unsecured debt" is defined as "debt not supported by collateral or other security." BlaCK'S LAW DiCTIONARY 411 (7th ed. 1999). "Secured debt" is defined as "debt backed by collateral." Id. The traditional state law method of enforcing unsecured debt when the debtor has defaulted is to sue the debtor in civil court. See JAMES J. White \& RAYMOND T. NimMER, CASES AND MATERIALS ON BANKRUPTCY 14 (2d ed. 1992) (describing briefly the history and modern forms of enforcing debt). Having satisfactorily demonstrated the existence of a debt and the debtor's failure to pay the debt, the creditor can obtain a writ of execution that allows her to request the local sheriff's services for seizure and sale of the property. Id. When debt is secured, the creditor does not need to use the courts to claim the property securing the debtor's obligation, if the property can be secured without breach of the peace. Id. at 23. Otherwise, the procedure for recovery will be similar to that of unsecured debt. If state remedies prove unworkable, creditors can force the liquidation of a corporation through federal bankruptcy laws. See 11 U.S.C. $\$ \$ 701-784$ (2000) (detailing the process of liquidation in bankruptcy proceedings); WHITE \& NIMMER, supra, at 59 (introducing Chapter 7 of the Bankruptcy Code, under which " $[t]$ he trustee simply collects the assets of the debtor, sells them, and distributes the proceeds to the creditors").

${ }^{16}$ See Dufey, supra note 10, at $45 \mathrm{n} .2$ ("Debt service is defined simply as the timely payment of interest."). 
firm's assets and the burden of its obligations. ${ }^{17}$ While a sovereign's ability to service its debt initially invokes a similar inquiry, it also involves political, social, and even moral questions. ${ }^{18}$ Rarely, if ever, though, is a country unable to meet its obligations in the same way a corporation is unable to meet its obligations. ${ }^{19}$ In almost all cases, a government can repay its loans as scheduled by diverting funds from other projects or by increasing taxes. ${ }^{20}$ The problem with this conclusion is that a country will always reach a point beyond which the costs of servicing its debts exceed the costs of defaulting on its obligations. ${ }^{21}$ Because of the elusive character of this calculation, it seems impossible to predict when this point will be reached. Furthermore, each change in political leadership presents a potentially different calculus for determining the costs of defaulting on sovereign debt.

The second difference between corporate and sovereign debt, therefore, is that a country can use little (if anything) to secure debt in the traditional sense. As a consequence, most sovereign debt remains "unsecured," which further frustrates collection remedies. In the corporate financing context, one of the major justifications for secured debt "is the desire to increase the likelihood of payment in the event of bankruptcy." ${ }^{22}$ Although there has been an ongoing debate over the value of secured debt generally, ${ }^{23}$ secured debt plays a major role in corporate bankruptcies. The absence of secured debt in

17 See WHITE \& NIMMER, supra note 15 , at 52 (recognizing that, when assets are inadequate to pay debts, troubled firms are dealt with through bankruptcy laws).

${ }^{18}$ See Jack Boorman, Sovereign Debt Restructuring: Where Stands the Debate?, Speech at a Conference Cosponsored by the Cato Institute and The Economist (Oct. 17, 2002) (describing the political, social, and moral threshold beyond which a country cannot justify further financial constraints), available at http://www.imf.org/external/ $\mathrm{np} /$ speeches/2002/101702.htm.

${ }^{19}$ This belief has led certain investors to comment that "countries never go bankrupt." Jeffrey D. Sachs, Introduction to DEVELOPING COUNTRY DEBT AND THE WORLD ECONOMY 1, 8 (Jeffrey D. Sachs ed., 1989) (quoting Citicorp Chairman Walter Wriston who justified heavy international lending with this rationale).

${ }_{20}$ See Boorman, supra note 18 ("Debt can almost always be serviced in some abstract sense, through additional taxation and through the diversion of yet more domestic production to exports to generate the revenue and foreign exchange needed to service the debt."). debt).

${ }^{21}$ See id. (acknowledging a threshold limitation to a country's willingness to service

${ }^{22}$ Steven L. Harris \& Charles W. Mooney, Jr., A Property-Based Theory of Security Interests: Taking Debtors' Choices Seriously, 80 VA. L. REV. 2021, 2067 (1994).

${ }^{23}$ See Robert E. Scott, The Truth About Secured Financing, 82 CORNELL L. REv. 1436, 1437 (1997) (examining "[t]he debate over the social value of secured credit" and inquiring when and why firms issue secured debt). 
the sovereign debt context limits the suitability of using domestic bankruptcy law as a model for sovereign debt restructuring.

Third, "the ability of a court to force a sovereign entity to comply with its wishes is extremely limited." ${ }^{24}$ As just explained, the traditional state law methods of debt collection ${ }^{25}$ are not applicable to sovereign debt. Further, no intergovernmental agency currently exists to adjudicate disputes between creditors and sovereign states. ${ }^{26}$ The absence of this structure is a major obstacle to any reorganization plan seeking implementation of domestic bankruptcy rules in the sovereign debt context.

\section{Historical Approaches to Dealing with Default}

In the last twenty years, there have been several periods of "crisis" during which numerous countries have simultaneously defaulted or have been in danger of defaulting. These crises have occurred in Latin America, Mexico, and most recently, Southeast Asia, ${ }^{27}$ and each has threatened the stability of the global economy, as well as the viability of the international financial markets. These debt crises are not a new phenomenon; similar lending booms and busts arose throughout the nineteenth century. ${ }^{28}$ As with more modern debt crises, each

${ }^{24}$ EATON \& FERNANDEZ, supra note 8, at 2.

${ }^{25}$ For a brief description of traditional state law remedies for debt delinquency, see supra note 15.

${ }^{26}$ The absence of an intergovernmental agency or other device to alleviate coordination problems among indebted countries was one of the major impetuses for the IMF's SDRM proposal. See infra notes 41-45, 53-56 and accompanying text (analyzing the collective action problem and explaining how the SDRM proposal would potentially resolve the issue).

${ }_{27}$ Generally, three distinct periods of crisis receive attention. In the early $1980 \mathrm{~s}$, Latin American countries were unable to meet their sovereign debt obligations and began to default. See Enrique R. Carrasco \& Randall Thomas, Encouraging Relational Investment and Controlling Portfolio Investment in Developing Countries in the Aftermath of the Mexican Financial Crisis, 34 Colum. J. TRANSNAT'L L. 539, 550-54 (1996) (discussing the origins of the financial crisis that occurred during the 1980s). In 1994, Mexico was unable to meet its financial obligations and threatened to disrupt all of Central America with its default. See Rory MacMillan, The Next Sovereign Debt Crisis, 31 STAN. J. INT'L L. 305, 305-07 (1995) (detailing the 1994 financial crisis and the U.S. government's orchestration of a rescue package totaling over $\$ 50$ billion). Finally, and most recently, the Southeast Asian markets experienced a financial crisis in 1997. See generally Duncan E. Williams, Note, Policy Perspectives on the Use of Capital Controls in Emerging Market Nations: Lessons from the Asian Financial Crisis and a Look at the International Legal Regime, 70 FordHAM L. REv. 561, 564-70 (2001) (describing the causes of the 19971999 Asian financial crisis).

${ }^{28}$ For example, the international community engaged in the practice of significant lending to sovereign states as far back as the 1850 s, late 1860 s, and late $1880 \mathrm{~s}$; 
occurrence has been characterized by euphoric increases in lending to foreign governments and eventual, thundering, and often disastrous cessations of that lending. ${ }^{29}$

Despite the recurring problem of sovereign debt repudiation, litthe evidence exists to suggest that "problem debtors" are actually punished. ${ }^{30}$ One would expect that problem debtors would at least be charged a higher interest rate commensurate with their sovereign risk. On the contrary, defaulting countries seem to obtain similar interest rates to those countries that repay their debts. For example, "[b]etween 1976 and $1979 \ldots$ the same interest premia were charged to those Third World countries that had repaid faithfully in the past and those who had not." ${ }^{31}$ Left unchecked, the problem seems destined to repeat itself.

History notwithstanding, there is a growing sense that financial crises have become more severe in recent years. ${ }^{32}$ As financial markets become more integrated, problems in one country can mean problems for an entire region, if not the world. In recognition of this reality, intergovernmental organizations like the IMF and the World Bank have sought to intervene in these financial crises, often by "bailing out" the defaulting country. Yet these bailouts have been provided on

continued the practice from 1904 to 1914; and reinstituted it again in the late 1920s. See Peter H. Lindert \& Peter J. Morton, How Sovereign Debt Has Worked, in DeveloPING COUNTRY DEBT AND THE WORLD ECONOMY, supra note 19, at 225, 226 (charting the history of sovereign debt repayment from the early nineteenth century to the 1920s).

${ }^{29}$ See id. ("Each wave ended with at least some occurrence of repayments breakdown, sometimes because of international trade depression, sometimes because of government budget crises, and sometimes because of revelation of financial abuses.").

${ }^{30}$ See id. at 232 (examining the historical data and finding no perceivable punishment for "problem debtors").

${ }^{31}$ Id.

${ }^{92}$ See, e.g., Desmond Lachman, Letter to the Editor, IMF Should Blow the Whistle, FIN. \& DEV., Dec. 1, 2003, at 2 (noting that the lack of access limits on IMF lending since 1995 has resulted in "moral hazard" lending, which "has tended to delay debt crises and to make them more severe when they eventually occur"). But see Ross P. Buckley, A Tale of Two Crises: The Search for the Enduring Reforms of the International Financial System, 6 UCLA J. INT'L L. \& FOREIGN AFF. 1, 3 n.2 (2001) (arguing, with respect to large-scale multinational crises, that "[t]he [Latin American] debt crisis [of the 1980s] brought the international financial system to the edge of total collapse-the Asian crisis [of the 1990s] had no such effect"); Päivi Munter, Index Puts Price on Political Risk: Record Emerging Markets Investment Has Prompted a Stability Tracker, FIN. TIMES, Feb. 5, 2004, at 43 ("For the moment, analysts consider the risk of a systemic calamity in emerging markets low. This is because of more prudent fiscal policies in emerging countries. Many of them have also dismantled fixed currency regimes, a trigger for several previous debt crises."). 
a provisional basis, with most coming from the IMF. ${ }^{39}$ Furthermore, some argue that these bailouts increase not only the cost of default, but also the likelihood of future defaults. ${ }^{34}$

Consequently, there is growing recognition of the need for a more systematic, less ad hoc approach to the problem of sovereign risk. Although some still argue that the international financial market works best without governmental interference, ${ }^{85}$ most observers recognize the need for reform. ${ }^{36}$ Criticisms of IMF bailouts have led some scholars to look for new methods of dealing with the sovereign risk problem. ${ }^{37}$ This Comment will examine two such approaches, one proposed by IMF Director Anne Krueger and the other supported by the U.S. Treasury Department.

\section{THE NEW APPROACH OF THE IMF}

IMF Director Anne Krueger has proposed an innovative solution to the problem of sovereign debt. ${ }^{38}$ Her plan, summarized in an IMF pamphlet published in April of 2002, supports the adoption of an SDRM. $^{39}$ The SDRM would involve a statutory creation functioning much like an international bankruptcy court. The IMF pamphlet outlines the structural framework of the SDRM, the costs and benefits of the plan, and the appropriate legal basis for the restructuring

33 See generally Milena D. Makich-Macias, Note, The Effect of the International Monetary Fund Bailout on Emerging Growth Countries, 26 BROOK. J. INT'L L. 1755, 1764-79 (2001) (describing IMF bailouts in the 1990s involving Brazil, Indonesia, and Russia).

${ }^{34}$ See Schwarcz, supra note 1, at 957 (warning that IMF lending potentially creates a "moral hazard" that would increase the likelihood of future default).

${ }^{35}$ See, e.g., Charles W. Calomiris, The IMF's Imprudent Role as Lender of Last Resort, CATO J., Winter 1998, at 275, 275-90 (criticizing IMF intervention as a misguided reaction to financial crises).

${ }^{36}$ See, e.g., Lindert \& Morton, supra note 28, at 234 ("Countries that had defaulted in the past were significantly more likely to become problem debtors again. Yet defaulting governments have seldom been punished, either with direct sanctions or with discriminatory denial of later credit.").

${ }^{37}$ See, e.g., Schwarcz, supra note 1, at 966-67 (arguing for the adoption of an international convention for sovereign debt restructuring); see also Rogoff \& Zettelmeyer, supra note 1 (giving a broad overview of the intellectual predecessors to the SDRM proposal). The SDRM proposal, infra Part II, and the market-based approach, infra Part III, also emerged during this time of disagreement.

38 Anne Krueger first introduced this proposal in 2001. Krueger, supra note 4.

39 ANNE O. KRUEGER, INT'L MONETARY FUND, A NEW APPROACH TO SOVEREIGN DEBT RESTRUCTURING (2002), available at http://www.imf.org/external/pubs/ft/exrp/ sdrm/eng/sdrm.pdf. 
mechanism. The following description is derived primarily from this pamphlet. $^{40}$

\section{A. The Primary Concerns of the IMF}

The IMF identifies four core problems that the SDRM seeks to solve: the collective action problem, sovereigns' inability to bind minority creditors, fears concerning intercreditor equity, and finally, the problem of financing during the restructuring period.

The first problem the IMF considers pertains to the method for financing sovereign debt. ${ }^{41}$ No longer are sovereigns indebted to several large banks. Now traded securities serve as the primary means of financing sovereign debt. ${ }^{42}$ While this arrangement has improved the efficiency of the international financial market, ${ }^{43}$ it creates significant coordination problems for countries attempting to restructure their debt. These complications represent a collective action problem, ${ }^{44}$ which operates as follows. While it might be in the interests of all the creditors to negotiate collectively with the sovereign and restructure debt, it is in the interest of each individual creditor to hold out for a time. By holding out, the lone creditor hopes to force the sovereign to pay its obligation fully, while only partially paying its obligations to other creditors. The collective action problem thus stands as a significant barrier to sovereigns attempting to restructure their debt through negotiations with creditors. ${ }^{45}$

40 As this plan was debated and the political and practical obstacles to the SDRM emerged, compromises and refinements were included in the IMF plan. See INT'L Monetaky Fund, PIN No. 03/06, IMF Board Discusses Possible Features of a SOVEREIGN DEBT RESTRUCTURING MECHANISM (2003) (describing various concerns with the SDRM and methods for dealing with these concerns), available at http://www. imf.org/external $/ \mathrm{np} / \mathrm{sec} / \mathrm{pn} / 2003 / \mathrm{pn} 0306 . \mathrm{htm}$. The original proposal provides the foundation for the analysis in this Comment.

41 See KRUEGER, supra note 39, at 6-9 (describing the origins and characteristics of the collective action problem).

${ }^{42}$ See id. at 6 (noting the past decade's "shift away from syndicated bank loans toward traded securities as the principal vehicle for the extension of financial credits to sovereigns").

${ }^{43}$ Id.

44 See Schwarcz, supra note 1, at 960-61 (explaining the collective action problem).

${ }^{45}$ It should be clear that, in the days before traded securities, when there were fewer creditors, the impact of the collective action problem was less pronounced. Other factors have similarly diminished the problem of collective action in the past. These factors include "the relative homogeneity of commercial bank creditors, the contractual provisions of syndicated loans, and ... moral suasion applied by supervisory authorities." KRUEGER, supra note 39, at 6 (footnote omitted). 
A second, related problem is that sovereigns lack the ability to bind minority creditors. ${ }^{46}$ Even if a sovereign were able to overcome the collective action problem and work out a restructuring plan with all the major creditors, the sovereign would still have no mechanism for compelling smaller, minority creditors to accept the restructured deal. Smaller creditors "may consider that their best interests would be served by trying to free ride in the hope of ultimately receiving payments in line with their original contracts." ${ }^{47}$ Minority holdouts, however, create uncertainty in the restructuring process. Thus, without the ability to bind minority creditors, sovereigns are extremely limited in their capacity to restructure debt.

Creditors' fears about intercreditor equity pose the third major barrier to restructured workouts. ${ }^{48}$ Creditors worry that debtors will make payments to favored creditors, effectively reducing the amount available for those who remain. ${ }^{49}$ The IMF suggests that this fear will prevent any creditor from entering into negotiations with a sovereign absent guarantees that preferences will not be paid. ${ }^{50}$

One final problem discussed by the IMF involves financing during the restructuring period. ${ }^{51}$ A country, like any corporation, needs money to operate during the restructuring period, as well as finances to implement the restructuring plan. If this type of financing is not given priority status, little incentive exists for creditors to loan money to sovereigns who are in default. ${ }^{52}$ Such a disincentive could impair the restructuring process.

${ }^{46}$ See id. at 7 ("The absence of a mechanism that provides for majority action among a diverse set of creditors is a primary source of difficulties with collective action.").

${ }^{47} I d$. at 8 .

48 See id. at 8, 16 (addressing the need to protect creditor interests).

49 See id. at 8-9 ("[C]oncerns about inter-creditor equity stemming from debtors' decisions to make payments to certain favored creditors after suspending payments on other creditors may introduce delays.").

${ }^{50}$ See id. at 16 (recognizing that, in order to protect creditors' interests, the SDRM must ensure that the sovereign debtor will be prohibited from making payments to nonpriority creditors).

${ }^{51}$ See id. at 17 (discussing the problems in the current "legal framework" that priority financing would eliminate).

${ }^{52}$ See George G. Triantis, A Theory of the Regulation of Debtor-in-Possession Financing, 46 VAND. L. REV. 901, 901-28 (1993) (examining debtor-in-possession (DIP) financing and its relative importance in the bankruptcy scheme). 


\section{B. The SDRM Proposal}

The IMF's proposed solution to these problems suggests creating a mechanism it calls the SDRM, which would function similarly to U.S. bankruptcy courts. In the corporate debt context, bankruptcy courts address many of the same structural issues that plague sovereign debt including collective action problems, minority holdouts, intercreditor equity, and financing during the restructuring period. Ultimately, the goal of the IMF, through its SDRM program, is to create "a predictable, orderly, and rapid process for restructuring the debts of sovereigns." ${ }^{\text {"33 }}$ The IMF has borrowed several key components of U.S. bankruptcy law that it believes will help in achieving this goal. To oversee the SDRM process, the IMF proposed the creation of an international bankruptcy court, over which the IMF will have control and oversight. $^{54}$

"[T]he most important element of any new restructuring framework" would be a mechanism to allow "a qualified majority of credi-

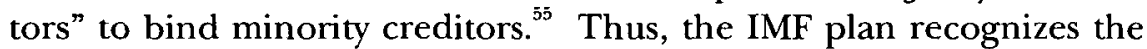
collective action problem as the most significant barrier to sovereign debt restructuring. The IMF utilizes a bankruptcy-like arrangement as it proves one of the few methods for avoiding the collective action problem. $^{56}$

To deal with the minority holdout issue, the IMF proposes a stay on litigation by creditors during any restructuring period. ${ }^{57}$ This requirement remains curious because, as the IMF recognizes, litigation against sovereigns is rarely effective. ${ }^{58}$ Nevertheless, the IMF proposal

53 KRUEGER, supra note 39 , at 2.

54 Id. at 23.

55 Id. at 14.

${ }^{56}$ This approach by the IMF is, to some degree, self-serving. As noted later in this Comment, infra Part III, many feel it is possible to simply contract out of the collective action problem. Adopting the IMF proposal ensures future IMF intervention in international financial crises, which may or may not be beneficial. One of the major criticisms of the IMF plan is that it gives the IMF too many new powers. See, e.g., Battling over the Bankrupt, ECONOMIST, Oct. 5, 2002, at 70, 70-71 ("[B]ankers and politicians complained that this idea gave the IMF too much power ...."). Responding to such criticism, the IMF altered its original proposal in an attempt to place the focus on creditors and to limit the focus on the IMF. Supra note 40.

${ }^{57}$ See KRUEGER, supra note 39, at 15-16 (pointing out the benefits of implementing a temporary stay on creditor litigation after a suspension of payments).

58 See id. at 16 ("The risk of widespread creditor litigation may be less pronounced in the sovereign than in the corporate context, largely on account of the relative scarcity of assets under the jurisdiction of foreign courts that could be seized to satisfy creditors' claims."). 
suggests that the mere possibility of litigation could be sufficient to hamper restructuring efforts because the uncertainty created by pending litigation might prevent creditors from restructuring. ${ }^{59}$

The IMF is not alone in proposing a stay on litigation in the sovereign debt arena. Indeed, some of the other leading proposals advocating for an international bankruptcy scheme also include stay provisions. ${ }^{60}$ It is unclear how necessary these provisions ultimately are when the threat of litigation is so small. Thus, the implementation of a stay might be an example of the inherent problems associated with analogizing between corporate finance and sovereign financing. In contrast to sovereign debt scenarios, stay provisions are vital to corporate bankruptcy proceedings because the threat of litigation is very real and those creditors who quickly file suit to recover on defaulted loans can potentially dismantle even viable companies.

The IMF proposal additionally requires that the SDRM balance the interests of creditors outside of a litigation context. The sovereign would first be prevented from making any payments to nonpriority creditors. $^{61}$ Further, the IMF would have oversight and control over the sovereign's ability to exhaust resources, which would serve to reassure creditors that the debtor will "conduct policies in a fashion that preserves asset values." ${ }^{29}$ Finally, the SDRM would grant priority to creditors giving new money during the stay period. ${ }^{63}$ Without this priority feature, there would be no incentive for a creditor to lend to a debtor in default. Providing priority to these creditors encourages a market for restructuring financing and facilitates the entire restructuring process. ${ }^{64}$

${ }^{59}$ See id. at 13 (arguing that, although litigation in this context is rare, the evolution of legal strategies has increased the uncertainties of post-default restructurings).

${ }^{60}$ See Schwarcz, supra note 1, at 984-85 \& nn.164-71 (citing various arguments raised by scholars for the inclusion of a stay provision).

${ }^{61}$ See KRUEGER, supra note 39 , at 16 ("[T]he sovereign debtor would be required not to make payments to nonpriority creditors."). Priority creditors are those creditors who have a right to be paid before any other creditors of the debtor. BLACK'S LAW DICTIONARY, supra note 15 , at 1212 . Nonpriority creditors must wait until all the priority claims are satisfied before they can recover any debts.

${ }^{62}$ KRUEGER, supra note 39, at 16.

${ }^{63} \mathrm{Id}$. at 17.

${ }^{64}$ The concept of priority financing mirrors current domestic bankruptcy law. The Bankruptcy Code authorizes certain post-petition financing to be given superpriority status over all other claims prioritized in section 507. 11 U.S.C. $\$ \$ 364$ (c), 503(b), 507 (2000); see also WHITE \& NIMMER, supra note 15, at 202-03 (reviewing the priority levels of financing). 
These elements of the SDRM are designed to create a "predictable, orderly, and rapid process" of sovereign debt restructuring to accord with the IMF's ultimate goal. ${ }^{65}$ In addition to the SDRM's specific elements, the IMF plan anticipates that the mere existence of the SDRM will itself encourage independent negotiations between creditors and sovereigns without having to resort to its complex procedures. ${ }^{66}$

The IMF concludes its proposal by advocating implementation of the SDRM "through the establishment of universal treaty obligations. $^{, 67}$ The IMF argues that this approach is superior to one in which each sovereign independently enacts legislation to approve the adoption of the SDRM. ${ }^{68}$ A universal treaty will insure uniformity because it will not be subject to the interpretation of each country's legislature (or other ruling body). The IMF further contends that, without universal obligations, a disincentive for each individual country to adopt the SDRM would emerge because the first few adopters may worry that its enactment signals a lack of confidence in their ability to repay sovereign debt. ${ }^{69}$ Adopting a universal treaty will have the effect of simultaneously enacting a uniform mechanism for dealing with sovereign debt.

\section{Reaction to the IMF Approach}

While the IMF proposal has been well received in many countries, ${ }^{70}$ some still believe that the plan is unrealistic or, even worse, detrimental to international financial markets. ${ }^{71}$ Some critics voice skepticism over the creation of an international bankruptcy court. ${ }^{72}$

${ }^{65}$ Supra text accompanying note 53.

${ }^{66}$ KRUEGER, supra note 39 , at 4 .

${ }^{67}$ Id. at 33 .

68 Id.

${ }^{69}$ These countries' concerns center around a "free rider" problem. Id. at 34. Absent universal treaty obligations, the first countries to adopt the SDRM will bear the risk that creditors will not approve of SDRM provisions and thus will penalize the adopting countries through higher interest rates and/or reduced lending.

${ }^{70}$ See Felix Salmon, Market Resists Restructuring Reform, EUROMONEY, Oct. 2002, at 18 (stating that, at a recent IMF meeting, the SDRM proposal was "endorsed by everyone who matters").

${ }_{71}$ See id. at 18-19 (identifying private sector opposition and borrowers' concerns).

${ }^{72}$ See Samuel E. Goldman, Comment, Mavericks in the Market: The Emerging Problem of Hold-Outs in Sovereign Debt Restructuring, 5 UCLA J. INT'L L. \& FOREIGN AFF. 159, 174 (2000) (recognizing that, because sovereigns will not likely relinquish power to any 
Others see more fundamental flaws in the SDRM. If the SDRM is effective in its stated goal of producing a predictable, orderly, and rapid restructuring process, it will have the simultaneous effect of reducing the cost of default. ${ }^{73}$ Creditors fear that reducing the cost of default will ultimately encourage sovereign nations to default. ${ }^{74}$ Further, debtors (sovereign borrowers) fear that creditor concerns about the reduced cost of default will mean an increase in the cost of borrowing to offset the perceived increased risk of default. ${ }^{75}$

Several authors have suggested that countries are supporting the SDRM as a means to achieve what they really want, which is the inclusion of collective action clauses in debt instruments provided to developing countries. ${ }^{76}$ It is important to note that there is a significant difference in the approach taken by the IMF (and the countries which support the SDRM) and that taken by the users of the system, the creditors and debtors, who have rejected the system outright. The users of the system view the primary benefit of the SDRM, increased predictability with a subsequent reduction in the cost of defaulting, as its biggest flaw because the users are concerned that this situation will encourage sovereign nations to default on their debt (and ultimately raise the cost of borrowing).

\section{MARKET-BASED APPROACH}

\section{A. The Treasury Department and Collective Action Clauses}

The day after the IMF announced its ambitious plan to enact an international bankruptcy court, the U.S. Department of the Treasury responded with its own ideas about the proper way to solve future sovereign debt crises. The Treasury Department plan, presented by Secretary of the Treasury Paul O'Neill, rejected the idea that an SDRM or any other statutory solution was necessary to address future economic

international body, an international bankruptcy court will face enforcement problems).

${ }^{3}$ See Salmon, supra note 70, at 18, 20 (listing the unintended and undesirable consequences of the SDRM).

${ }^{74} I d$.

${ }^{75}$ Id. at 20.

${ }^{76}$ Battling over the Bankrupt, supra note 56, at 70 ("Nobody knows if rich countries ... are merely using the SDRM threat to corral investors and emerging-market countries into accepting collective-action clauses."). 
concerns. $^{77}$ The Treasury Department, convinced about the virtue of market solutions, ${ }^{78}$ proposed the idea of encouraging creditors and debtors to rewrite the way bonds were written in an attempt to alter the terms under which countries borrowed money. ${ }^{79}$

Just like the IMF's SDRM proposal, the Treasury Department's plan was not uniquely conceived. ${ }^{80}$ Similar ideas have been examined in academic journals over the past several years. ${ }^{81}$ In fact, some of the major criticisms of the Treasury Department's plan claim that it is identical to a 1996 G-10 proposal that proved unworkable and that it is simply an old plan regurgitated. ${ }^{82}$

The Treasury Department has chosen to emphasize a different set of concerns than the IMF. According to the Treasury Department, the primary problem with sovereign debt restructuring is the lack of a

77 See The U.S. Department of the Treasury's Report to Congress on International Economic and Exchange Rate Policy: Hearing Before the Senate Comm. on Banking, Hous., EF Urban Affairs, 107th Cong. 52 (2002) (statement of Secretary Paul H. O'Neill, U.S. Dep't of the Treasury) (testifying that the Bush administration advocates a "market-oriented approach to the sovereign debt restructuring process").

${ }^{78}$ See id. ("The swift removal of barriers in key markets will help strengthen financial systems internationally.").

${ }^{79} I d$.

${ }^{80}$ See Rogoff \& Zettelmeyer, supra note 1 (surveying the intellectual history of sovereign debt restructuring proposals).

${ }^{81}$ See, e.g., Buch heit \& Gulati, supra note 1, at 1358 n.87 (identifying a number of sources that support the use of collective action clauses); EICHENGREEN \& MODY, supra note 1 , at 22-23 (noting the benefits of collective action clauses).

${ }^{82}$ See Michelle J. White, Sovereigns in Distress: Do They Need Bankruptcy?, 2002 BROOKINGS PAPERS ON ECON. ACTIVITY 287, 308 (criticizing the collective action clause proposal on the grounds that international financial institutions have been advocating similar solutions for years, "with little effect"). "To answer the objection that the current [Treasury Department] position is not much different from the line taken in the Rey Report of the G-10 . . the US Treasury proposed adding substantial 'carrots and sticks' as incentives to change." MARCUS MILLER, SOVEREIGN DEBT RESTRUCTURING: NEW ARTICLES, NEW CONTRACTS-OR No CHANGE? 6 (Inst. for Int'l Econ., Int'l Econ. Policy Briefs No. PB02-3, 2002), available at http://www.ciaonet.org/frame/pbeifrm. html. The G-10 proposal surfaced after the Mexican financial crisis in 1996 and proposed the inclusion of collective action clauses into bond contracts, with the IMF serving as a backstop. GROUP OF TEN, THE RESOLUTION OF SOVEREIGN LIQUIDITY CRISES: A REPORT TO THE MINISTERS AND GOVERNORS PREPARED UNDER THE AUSPICES OF THE DEPUTIES II I 3, 53-56 (1996), available at http://www.bis.org/publ/gten03.pdf; MILLER, supra, at 11. The government also verbally responded to the criticisms. See John B. Taylor, Using Clauses to Reform the Process for Sovereign Debt Workouts: Progress and Next Steps, Remarks at the EMTA Annual Meeting (Dec. 5, 2002) (arguing that "not all old ideas are bad" and deflecting criticism by stating that the Treasury Department proposal "went well beyond traditional collective action clauses"), available at http://www.treas.gov/press/releases/po3672.htm. 
process to restructure debt. ${ }^{83}$ With no process in place, investors are unable to adequately assess the cost of default. Without this information, not only are bonds priced inaccurately, but great uncertainty ensues when a country has debts that are unmanageable. With that latter concern in mind, the more modest goal of the Treasury Department is to "reduce the uncertainty that now surrounds restructurings. ${ }^{84}$

The Treasury Department does not specify the kind of restructuring procedure it would like to see implemented. Having faith in the market system, the Treasury Department leaves the terms of the process up to the individual creditors and debtor nations. Major statutory reforms are not required, nor is the creation of an international bankruptcy court. If debtors and creditors are given incentives to include contractual provisions relating to restructuring in their loans, uncertainty will be reduced, and the markets will function more efficiently (and, hopefully, with fewer defaults). ${ }^{85}$

According to the Treasury Department, the creation "of a clear, well-defined [restructuring] process" ${ }^{\$ 6}$ can be accomplished contractually (i.e., without major statutory revisions). The Treasury Department proposes the inclusion of three different types of clauses into bonds used to finance sovereign debt. The first of these clauses is a collective action clause, which is designed to "allow a super-majority of bondholders to alter the key financial terms of a bond." ${ }^{87}$ While the Treasury Department does not define which financial terms would be subject to the collective action clause, a review of the academic literature suggests that "financial terms" refers to either a change in the due date for the payment of a bond's principal or interest or a reduction of the interest or principal on the bond. ${ }^{88}$ Currently, these financial terms cannot be changed in over seventy percent of the bonds

${ }^{83}$ See Taylor, supra note 82 (suggesting that the lack of a definitive process for dealing with sovereign debt presents "a design weakness . . that impedes broader participation in the market").

${ }^{84}$ John B. Taylor, Sovereign Debt Restructuring: A U.S. Perspective, Remarks at the Conference, Sovereign Debt Workouts: Hopes and Hazards?, Institute for International Economics (Apr. 2, 2002), available at http://www.treas.gov/press/releases/po2056.htm.

${ }^{85}$ But see supra Part II.B (discussing the alternative IMF solution that encourages the implementation of uniform obligations, rather than individual contractual provisions, in an effort to overcome the collective action problem).

Taylor, supra note 82.

${ }^{87} I d$.

${ }^{88}$ See Lee C. Buchheit \& G. Mitu Gulati, Exit Consents in Sovereign Bond Exchanges, 48 UCLA L. REV. 59, 63 (2000) (noting the use of these financial terms in "consensual restructuring" of bonds). 
outstanding to sovereign nations. ${ }^{89}$ However, if creditors included the authority to alter such terms in their bonds, then the cost of coordinating negotiations during restructuring would be significantly reduced.

The second type of clause the Treasury Department wants included in all newly issued debt instruments provided to emerging markets is an engagement clause..$^{90}$ This clause is designed to "describ [e] the process through which debtors and creditors come together in the event of a restructuring," ${ }^{, 1}$ giving debtors and creditors the opportunity to flesh out some of the specific details regarding the actual process of restructuring. The Treasury Department suggests that this clause could include the designation of a creditor representative-an individual or group of individuals chosen to negotiate on behalf of all the creditors ${ }^{92}$ - who would have the exclusive right to initiate litigation against the sovereign. ${ }^{93}$ This provision, like that of the IMF proposal, ${ }^{94}$ appears to be designed to attack the minority holdout problem. In addition, the engagement clause could be used to specify both the information the debtor must provide to the creditor representative and the timeframe for providing that information. The implementation of this clause will likely establish specific guidelines for the parties to follow.

Finally, the Treasury Department is advocating for the inclusion of what it calls an initiation clause. ${ }^{95}$ This clause describes the procedure

${ }^{89}$ See Taylor, supra note 82 (recognizing that only about thirty percent of current emerging-market sovereign bonds include collective action clauses).

${ }^{90}$ In his April 2002 remarks, John Taylor described what an engagement clause should entail but did not refer to it by the name "engagement clause." See Taylor, supra note 84 (recommending the use of a clause that would specify the roles of creditors and debtors in a restructuring scenario). It was not until a December 2002 speech at the EMTA's annual meeting that Taylor used the term "engagement clause" to describe the provision he had earlier introduced. Taylor, supra note 82.

91 Taylor, supra note 84.

92 Taylor is only proposing that the clause bind all those bondholders within a specific class of bonds; the clause would not bind creditors generally. Cf. Part II.B (proposing that an essential aspect of a new restructuring framework would be a system by which a majority of creditors could bind minority creditors).

${ }^{93}$ See Taylor, supra note 84 ("The representative, rather than individual bondholders, would have the power to initiate litigation...."). This provision is conditioned by the fact that the creditor's representative would have to act with the instructions of a certain percentage of bondholders. Id.

${ }^{94}$ See supra notes 55-59 and accompanying text (describing the IMF-supported arrangement for addressing the minority holdout problem).

${ }_{95}$ Though Taylor provided a brief description of the clause in his April 2002 speech, see Taylor, supra note 84 (outlining a clause proposal that would set aside a 
by which a sovereign country initiates the restructuring process. ${ }^{96}$ Ideally, the sovereign would notify the creditor's representative (as defined by the engagement clause), and the two groups would begin negotiating a restructured deal. The quicker the process can occur, the more asset value will be protected. Significant coordination problems remain, however. The sovereign must be given time to notify and properly document the need for restructuring, while, at the same time, the creditor's representative must determine its respective bargaining position.

An interesting aspect of the Treasury Department's proposal concerning the initiation clause is its suggestion that the parties may wish to include a "cooling-off" period during which no litigation may be initiated against the sovereign. ${ }^{97}$ This feature is similar to the stay provision in the IMF's SDRM plan, ${ }^{98}$ but its existence is curious in this context. Its stated purpose is to prevent bondholders from initiating litigation. However, as mentioned above, with the adoption of an engagement clause, only the creditor's representative will have the authority to initiate litigation. ${ }^{99}$ Treasury Department documents do not clearly express the intent of this cooling-off period provision.

\section{B. Reaction to Collective Action Clauses}

Not surprisingly, some of the most poignant criticism of collective action clauses comes from the IMF and its director, Anne Krueger. Perhaps anticipating the Treasury Department proposal that was to follow exactly one day after the SDRM proposal, Krueger launched a

period of time during which creditors could communicate with one another and decide upon a course of action), he did not actually refer to it as an "initiation clause" until the EMTA's annual meeting eight months later. Taylor, supra note 82.

${ }_{97}^{96}$ Taylor, supra note 84 .

${ }^{97}$ See id. ("[T]here is a need for a 'cooling off period[] between the date when the sovereign notifies its creditors that it wants to restructure and the date that the representative is chosen .... During this limited cooling off period, bondholders would be prevented from initiating litigation.").

${ }^{98}$ See KRUEGER, supra note 39, at 21-28 (describing the IMF's potential role within a sovereign debt restructuring framework involving stay provisions); supra notes 57-59, 65-66 and accompanying text (explaining the requirements of the IMF's proposed stay provision and the rationale behind it).

${ }_{99}$ See supra notes 92-93 and accompanying text (suggesting that the engagement clause specify a creditor representative who would negotiate on behalf of all the bondholders of a specific bond). 
preemptive, multifaceted attack against market-based approaches and insisted that a statutory scheme was the only meaningful solution. ${ }^{100}$

Krueger believes that, initially, it will be difficult to provide sufficient incentives to encourage creditors and debtors to include collective action clauses voluntarily. ${ }^{101}$ Under Secretary of the Treasury for International Affairs John Taylor rejects this criticism, but provides no evidence to support his view. ${ }^{102}$ The fact that the Treasury Department's proposal was virtually identical to a 1996 proposal from the G10 that did not meet with much success ${ }^{103}$ suggests that Krueger might be right. Furthermore, evidence from emerging markets indicates the reluctance of sovereigns to negotiate for these clauses out of fear that their implementation will increase borrowing costs. ${ }^{104}$

One of Krueger's more effective criticisms is that collective action clauses would be exceptionally limited in that they would only bind bondholders within the corresponding issue. ${ }^{105}$ If that is the case, there are significant forms of debt, including bank loans, trade credit, domestic debt, and official claims, that would escape the grasp of the restructuring process. ${ }^{106}$ Failing to include these forms of debt creates substantial uncertainty as to the resources available for any possible restructuring. Considering that the Treasury Department's goal is to maximize certainty in the restructuring process, this criticism proves damning.

The above analysis did not escape the Treasury Department. While it did not deny the potential problems, the Treasury Department

100 See KRUEGER, supra note 39, at 29-40 (arguing that a statutory framework is the most effective mechanism for addressing collective action problems).

${ }^{101} I d$. at 32 (" $[\mathrm{I}] \mathrm{t}$ can be expected that certain creditor groups would be particularly reluctant to agree voluntarily to an arrangement whereby, for voting purposes, their claims were aggregated with all other present or future creditors.").

${ }^{102}$ See Taylor, supra note 82 (demonstrating support for collective action clauses by enumerating all the countries that either are committed to using collective action clauses or have made statements in favor of incorporating such clauses).

${ }^{103}$ See supra note 82 and accompanying text (noting the possible regurgitation of the 1996 G-10 plan).

${ }^{104}$ In a recent article, Mexico's Finance Minister Francisco Gil Diaz bristled at the suggestion that borrowing nations desired the inclusion of collective action clauses in any bond instrument. Minister Diaz stated that no collective action clauses were included in their most recent bond issued on September 17, 2002, and that Mexico had never considered including such clauses in past bonds. Battling over the Bankrupt, supra note 56 , at 70 .

${ }^{105}$ KRUEGER, supra note 39 , at 15.

${ }^{106}$ See id. (explaining that, because majority restructuring provisions only bind bondholders within the same issue, "they do not apply to other types of indebtedness, such as bank claims and domestic debt"). 
attempted to focus attention on the benefits of the program instead. Importantly, though, the Treasury Department's proposal is not intended to address all future sovereign debt crises; it is more limited in scope. Indeed, the proposal is subject to broad criticism, primarily because of its limited scope. The Treasury Department recognizes that its proposal will not prevent all future sovereign debt crises and that additional remedies are needed to address some of the larger, more complex issues regarding sovereign debt. ${ }^{107}$ This limited solution, however, is easily incorporated, inexpensive, and a good first step toward a resolution of future crises. ${ }^{108}$

The SDRM proposal by the IMF and the collective action clauses suggested by the Treasury Department highlight unique perspectives about the way future sovereign debt crises should be handled and, perhaps, avoided. However, the differences between the two proposals are not just procedural. Each organization is advocating an approach to restructuring foreign debt based on different underlying beliefs about the purpose of bankruptcy law. ${ }^{109}$

\section{COMPETING VALUES REPRESENTED IN BANKRUPTCY THEORY}

Professor Douglas Baird believes that the debates surrounding bankruptcy law are more than debates about the sufficiency of empirical evidence. ${ }^{110}$ Baird suggests that there is a more fundamental reason why two major competing groups appear in the bankruptcy debates that occur both in the practice and scholarship of the field. He claims that the two groups start from different axioms and that their

107

See Taylor, supra note 84 (cautioning that " $[\mathrm{t}]$ his proposal for reform ... should [be] viewed as an integral part of our broader strategy toward emerging markets"); see also Taylor, supra note 82 (recognizing that the market-based approach is but a component of the administration's overall emerging market strategy).

${ }^{108}$ See Taylor, supra note 82 (suggesting that, because the clause approach is more decentralized than the SDRM approach, the clause option could be implemented more quickly and that, even if its scope is not as broad as the SDRM's, "if only a few crises could be prevented, reforming the restructuring process should still be a high priority").

${ }^{109}$ See, e.g., Schwarcz, supra note 1, at 975-80 (reviewing the conceptual foundation for Chapter 11 bankruptcy law and arriving at "normative underpinnings" for a sovereign debt restructuring framework). Professor Steven Schwarcz's article provided the animus for this Comment's use of Professor Douglas Baird's work to uncover the conceptual foundations for the SDRM and the collective action clause models.

${ }^{110}$ Douglas G. Baird, Bankruptcy's Uncontested Axioms, 108 YALE. L.J. 573, 573-74 (1998) ("[I]t would be a mistake to think that empirical studies [on bankruptcy law] will do much to end the current debates."). 
respective positions reflect this difference. ${ }^{111}$ To understand the full complexity of the sovereign debt restructuring debate, it is essential to examine the respective plans of each side to see if their differences also flow from different axioms. If they do, recognition of those differences could lead to a more complete understanding of the debate.

Baird divides the divergent groups into two distinct camps. Members of the first group are called traditionalists. ${ }^{112}$ Traditionalists believe that laws regarding bankruptcy are unique and distinguishable from other legal rules like those in tort or contract law. ${ }^{113}$ It is this recognition of "important and distinctive" substantive goals that distinguishes the traditionalists. ${ }^{114}$

Members of the second group, known as proceduralists, consist "almost entirely of academics." As their name indicates, proceduralists focus primarily on the procedural aspects of the restructuring process, trying to minimize the perceived uniqueness of bankruptcy rules. ${ }^{116}$ For them, it is important that any restructuring order or other mechanism be consistent with "the rest of the legal system" and that bankruptcy laws fit into, and are cohesive with, "a vibrant market economy."

Baird believes that the differences between these two distinct camps can be demonstrated by the way each group would answer three distinct questions because each group's answers reveal their underlying values and beliefs. While each question will be examined in detail below, an initial listing of the questions may be helpful. The first question asks what role bankruptcy law should play in keeping a

111 See id. at 574-75 (noting Baird's belief that the two divergent sets of axioms "stem not from different political beliefs but rather from radically different views of the underlying normative bases of the role of bankruptcy law and the aims of legal scholarship").

${ }_{112} I d$ at 576.

113 Id.

114 Id. For a typical example of a traditionalist approach, see Elizabeth Warren, Bankruptcy Policy, 54 U. CHI. L. REV. 775, 796 (1987) (arguing that a bankruptcy distribution scheme must address underlying substantive values by, for example, inquiring into who is hurt when a business fails, whether those losses can be avoided, and at what cost those losses should be avoided).

115 Baird, supra note 110 , at 576 .

${ }^{116}$ See id. at 577-78 ("[T] raditionalists believe that bankruptcy law serves an important purpose in rehabilitating firms that, but for bankruptcy protection, would fail [while] ... proceduralists deny that bankruptcy can work any special magic.").

${ }^{117} I d$. at 577. For a typical example of a proceduralist approach, see Robert $\mathrm{K}$. Rasmussen, An Essay on Optimal Bankruptcy Rules and Social Justice, 1994 U. ILL. L. REV. 1, 42 (contending that bankruptcy rules cannot remedy any existing inequality through asset distribution). 
firm intact as a going concern. ${ }^{118}$ This question involves the extent to which bankruptcy rules should give "second chances" to troubled firms. The second question involves the degree to which one can consider bankruptcy a closed or open system. ${ }^{119}$ This question examines the belief that rulings in bankruptcy have effects beyond those directly connected to the participants in the pending case. The final question inquires about the role the bankruptcy process should play in implementing specific substantive policies.

Proceduralists adopt an extremely austere view of the world with regard to what role bankruptcy law should play in keeping a firm intact. Proceduralists have no interest in preserving any firm that cannot function in a competitive market. ${ }^{121}$ The laws governing reorganization simply cannot change the market reality that "[m]ost firms fail." ${ }^{122}$

For proceduralists, bankruptcy rules do have an important function in a market economy; however, the scope of that function is extraordinarily narrow. Proceduralists often distinguish between economic and financial distress. ${ }^{123}$ A firm is in economic distress if "it cannot generate sufficient revenue to pay its debts." ${ }^{24}$ One example of a firm in economic distress would be a firm unable to "succeed in the marketplace, since competitors produce a better product at a lower cost." ${ }^{2125}$ Economic distress would exist even if a firm had no creditors. Financial distress is different in that it is directly related to the firm's capital structure. ${ }^{126}$ There are various reasons why otherwise wellpositioned firms experience financial distress, including large tort liabilities, incorrect future forecasts, and unforeseen events. ${ }^{127}$ Thus, a firm in financial distress encounters a temporary problem of being unable to pay back what it has borrowed, while a firm in economic distress cannot compete in the marketplace.

${ }^{118}$ Baird, supra note 110 , at 577.

119 Id. at 579 .

${ }^{120}$ Id. at $577-79$.

${ }^{121}$ See $i d$. at 580 (noting that, under the proceduralist view, " $[\mathrm{k}]$ eeping firms intact that cannot effectively compete results in more harm than good over the long run").

${ }^{122}$ Id.

${ }^{123} I d$. at $580-81$.

${ }^{124} I d$. at 580 .

${ }^{125}$ Id.

${ }^{126}$ See id. at 581 ("Financial distress exists only if a firm has creditors. If the creditors disappeared, the problem would disappear and the firm would thrive.").

${ }^{127}$ See id. (remarking that an effectively managed firm may still experience "huge tort liabilities" and cost overruns). 
Addressing the role that bankruptcy should play in keeping a firm intact, proceduralists are only willing to extend the protection of the law to firms experiencing financial distress. ${ }^{128}$ In the complex world of corporate financial management, even well-managed firms can experience periods of illiquidity. It is during these times that society, through reorganization procedures, can protect the asset values of the firm and keep the firm intact. On the other hand, firms experiencing economic distress should not be extended protection. Proceduralists believe that these firms should be left subject to market forces because the market has determined them to be inadequate. ${ }^{129}$ There is no reason to keep such a firm intact.

Traditionalists often fail to differentiate between economic and financial distress. For traditionalists, protecting a business through bankruptcy rules serves an independent good. A business is not just a balance sheet; a business is also a distributor of wages for its employees, a source of trade for its suppliers, and often a provider of services to a community. When a business closes, the costs to these groups are substantial. Traditionalists argue that, if bankruptcy laws allow creditors to easily dismantle a firm "in pursuit of their narrow selfinterests"130 (i.e., recovery of their loans), these laws will discount the social costs associated with the closing of a business. ${ }^{131}$ Therefore, traditionalists argue, bankruptcy laws should be used more liberally to give firms a "second chance" and serve as a bulwark to the harshness of market forces. ${ }^{132}$ This recommendation does not mean to imply that every firm should be prevented from failing but that the distressed firm should be given every opportunity to succeed.

Baird's second inquiry asks whether bankruptcy should be considered a closed or open system. ${ }^{133}$ Generally, this question is designed to determine the extent to which traditionalists and proceduralists believe that the rules of bankruptcy and decisions of bankruptcy courts have effects beyond the immediate case or controversy.

$128 I d$.

129 In the corporate context, leaving economically distressed entities to market forces will generally result in the liquidation of the firm. This idea is captured in Baird's summation of the proceduralist's perspective: "A market economy works when firms that cannot compete effectively are allowed to fail.” $I d$. at $\mathbf{5 8 2 .}$

Id. at 583 .

191 Id. at $582-83$.

132 Id.

${ }^{133} I d$. at 578. 
Proceduralists believe that bankruptcy rules affect behavior elsewhere, particularly the investment decisions of creditors. ${ }^{134}$ For example, consider the traditionalist goal of creating breathing room for distressed firms, potentially giving them a second chance at success, despite their inability to meet their current obligations. From the proceduralist perspective, this second chance comes at the expense of the creditors, who, but for the bankruptcy proceeding, could liquidate the firm and force a transfer of assets.

According to proceduralists, the traditionalist position also negatively implicates the consistency of the legal system. ${ }^{135}$ If worthy, independent, substantive values really do exist in bankruptcy law, why are these values absent from other areas of the law? ${ }^{136}$ If the traditionalist approach can prevent creditors from liquidating a firm because of concerns regarding the impact on the community, why do judges not have the authority to prevent an individual firm owner from closing down a business or relocating? The impact on the community is potentially the same; however, the law will not interfere with the business owners' rights to close their establishments. Proceduralists ask why the law should interfere with the creditors' rights to engage in analogous acts.

Initially, traditionalists respond by arguing that sparse evidence exists that bankruptcy rules affect investors' decisions ex ante. ${ }^{137}$ If investors' decisions are not affected, then there is little need to factor in their interests when determining the proper outcome in a bankruptcy proceeding. More important for the traditionalists is a balancing of the interests among the parties before the court. Traditionalists do not seek to deny the interests of creditors. However, as just discussed, traditionalists weigh the other side of the scale more heavily because they recognize the social costs created by failing firms. Therefore, judges in bankruptcy proceedings should be able to craft decisions that balance the interests of the parties before them and should not be overly concerned with the effects that their rulings may have on investors.

Traditionalists also reject the proceduralists' calls for consistency as "disingenuous." ${ }^{138}$ They argue that a bankruptcy proceeding is not

${ }^{134}$ Id. at 581-82.

${ }^{135}$ See id. at 590 ("Traditionalists support a type of judicial intervention . . . that legal scholars do not encounter elsewhere.").

${ }^{136} I d$.

137 Id. at 578.

${ }^{138}$ Id. at 592 . 
simply a process to ensure that markets are properly functioning. ${ }^{139}$ Divergent interests need to be balanced. Therefore, the judge in such a proceeding should keep nonmarket objectives in mind. ${ }^{140}$ This point leads the discussion into the final question posed to differentiate the two camps.

The proceduralist sees the bankruptcy process as long, costly, and devoid of any equivalent offsetting benefit. ${ }^{141}$ The dangers of a prolonged bankruptcy proceeding include increased litigation and uncertainty for future investors. The process should be short and sweet. For the proceduralists, "negotiations among the interested parties... are costs to be avoided." terested arbitrator. There should be a process to ensure disclosure of relevant information and a vetting of parties' biases, but the ultimate outcome should not be left to the judge. ${ }^{143}$ The outcome should be left to the creditors and debtor, without judicial interference.

The traditionalist does not have such a negative view regarding the bankruptcy process. In fact, for traditionalists, "the process is itself one of the great virtues of bankruptcy law."144 Through this process all the parties involved are able to congregate for purposes of discussing and negotiating the situation, the judge is able to cajole compromises, and the substantive goals of bankruptcy can be advanced. The process is of essential importance for traditionalists. According to their theory, judges must be given the discretion to craft creative solutions to problems created by "rich and textured facts." laic method of bankruptcy that failed to account for the uniqueness of each bankruptcy case would be sufficient for dealing with restructuring. Thus, the judge, in the traditionalist model, is more than a disinterested arbitrator. The "judge is a shepherd, whose job it is to push the flock in the desired direction."

${ }^{199}$ See id. (noting traditionalists' belief that proceduralists place too much faith in economic forces).

${ }^{140}$ See id. ("Bankruptcy judges should have aims in mind other than ensuring that markets work effectively.").

${ }_{141}^{142} I d$. at 593.
$I d$.
${ }_{143} I d$. at 579.
${ }^{144} I d$. at 593.
${ }_{145} I d$. at 579.
${ }_{146} I d$. 


\section{ANALysis of THE VALUES PRESENT IN THE SDRM and COllective ACTION Clauses}

To uncover some of the values present in the IMF and Treasury Department proposals, I will examine each proposal keeping in mind the differences between traditionalist and proceduralist views regarding the role of bankruptcy law. ${ }^{147}$

The two competing views regarding the role of bankruptcy law in keeping a firm intact cannot be directly transplanted to issues of sovereign debt. The inquiry must be altered slightly to account for sovereign debt's unique problems. For example, no country can be liquidated by its creditors, and so countries unable to satisfy their debts will nonetheless be "left intact," so to speak. Although the formal rules of bankruptcy cannot account for this difference, the underlying views of traditionalists and proceduralists illuminate and provide fresh perspectives on the two sovereign debt proposals.

The proponents of collective action clauses appear only minimally concerned with taking an active role in supporting a sovereign's efforts to maintain solvency. Collective action clauses focus on resolving an immediate dispute between the debtor country and a limited group of creditors. As explained above, they are extraordinarily restricted in their applicability; ${ }^{148}$ they do not apply to many other forms of debt that may constitute the true cause of the country's liquidity problems. The Treasury Department admits that collective action clauses do not address "other potential sources of financial crises." This approach remains content to allow the market to dictate the terms of the reorganization and, by dictating the terms, the ultimate outcome.

This stance is consistent with the proceduralist position regarding the role of bankruptcy. If indeed "[a]ll bankruptcy can do is ensure that fights among creditors... do not accelerate... liquidation," ${ }^{150}$ then there is no need for an elaborate international court of

${ }^{147}$ The novelty of my analysis is to utilize Baird's work to deconstruct two competing sovereign debt restructuring proposals. Other scholarship has examined Baird's theories to supplement an alternative to these two competing proposals. See generally Schwarcz, supra note 1, at 975-80 (utilizing bankruptcy theory to develop a normative framework for an alternative method of dealing with the problem of sovereign debt restructuring).

${ }^{148}$ See supra text accompanying notes 105-06 (describing Anne Krueger's criticism that collective action clauses prove particularly limited).

${ }^{149}$ Taylor, supra note 82.

${ }^{150}$ Baird, supra note 110 , at 578 . 
bankruptcy. While the Treasury Department approach does not advocate liquidating a country, it does not seem overly concerned with protecting it from harsh market forces. In fact, this approach lauds the market as the only accurate way to price the risk of restructuring. ${ }^{151}$ The idea that restructuring rules work best when they interfere only minimally with the international financial market parallels a purely proceduralist approach to bankruptcy. ${ }^{152}$

The SDRM, on the other hand, answers this basic question quite differently. It sees a different role for the reorganization process. The SDRM is described as an approach that will "pav[e] the way toward an agreement that helps the debtor return to viability and growth." 153 The SDRM wants to protect the "national ... prosperity" of the debtor nation in addition to asset values and creditors' rights. ${ }^{154}$ There is a clear understanding throughout the IMF proposal that the costs considered during the restructuring process were not restricted to the financial recalculations of debt. Indeed, there is a distinct recognition of the role an international bankruptcy court could play in minimizing the harshness of market forces. ${ }^{155}$ Just as traditionalists want to give breathing room to troubled firms, the SDRM, through stay provisions and priority financing, would provide temporary assistance to debtor nations. ${ }^{156}$ This assistance is not something provided for in the collective action clauses.

In considering whether bankruptcy should be a closed or open system, each approach seems again to suggest a different answer. The proponents of collective action clauses have no doubt that the bankruptcy proceeding has ex ante effects on investors. In fact, the entire argument for collective action clauses seems to center around improving, ex ante, investors' decisions. As stated above, the goal of collective action clauses is to create certainty regarding the restructuring process. ${ }^{157}$

151 See Taylor, supra note 82 (suggesting that " $[\mathrm{t}]$ he lack of a clear, well-defined process for sovereign debt workouts ... prevents the market from accurately pricing the risk of a restructuring event"); supra text accompanying notes 84-85 (noting the Treasury Department's faith in the market system that translates into a proposal that would leave the terms of the process up to the individual creditors and debtor nations).

See Baird, supra note 110, at 587 ("For [proceduralists], bankruptcy law works best when it interferes as little as possible with the operation of markets.").

${ }^{153}$ KRUEGER, supra note 39, at 2.

154 Id. at 21.

${ }^{155}$ See id. at 4 (commenting that a properly designed SDRM would increase the efficiency of the international capital market).

${ }^{156}$ Id. at $25-28$.

${ }^{15 \%}$ Supra text accompanying notes 84-89 and p. 1502. 
This goal is important because uncertainty "impedes broader participation in the markets." In In effect, uncertainty "prevents the market from accurately pricing the risk" of default. ${ }^{159}$ This market-based approach focuses on the belief that bankruptcy is an open system and that any regulations governing restructuring will significantly impact decisions made elsewhere.

The SDRM approach to whether sovereign restructuring should be an open or closed system does not fit neatly into either the traditionalist or proceduralist camp, although it appears to favor the traditionalist side. The reason the SDRM is not wholly traditional in its approach is that it seems to recognize and place importance on ex ante effects. ${ }^{160}$ For instance, its advocates posit that proper implementation of the SDRM would result in benefits such as an increased efficiency of the international capital market and a better global allocation of capital, effects primarily due to the SDRM's more reliable procedural mechanisms. ${ }^{161}$ The fact that the proponents identify these benefits prevents them from taking a completely traditionalist perspective.

The SDRM does a much better job at "employing the idea of "balance." "162 Although the improved efficiency of the markets is recognized, it is the last benefit listed in a group of benefits that also includes allowing the debtor to avoid severe economic dislocation and preserving official reserves. ${ }^{163}$ The sole aim of the SDRM is not to establish a framework that provides more information to a captive audience of investors. Rather, it contemplates that the rules governing reorganization should do more than ensure that markets work efficiently. This view, then, seems more consistent with the traditionalist approach than it first appeared.

The final question involves a determination of the role that the process of reorganization plays in implementing substantive policies. The Treasury Department's approach on this question is unabashedly proceduralist. As Baird explains, proceduralists believe that "parties [in bankruptcy] have to make their own decisions; the judge is not to make choices for them. Rather than being committed to any

${ }^{158}$ Taylor, supra note 82.

${ }^{159} I d$.

${ }^{160}$ See Baird, supra note 110 , at 589 (stating that "traditionalists do not even directly discuss ex ante effects").

${ }^{161}$ KRUEGER, supra note 39, at 5.

${ }^{162}$ Baird, supra note 110 , at 589.

${ }^{169}$ KRUEGER, supra note 39, at 5. 
particular outcome, the judge should control the process to ensure that ... all relevant information is gathered and disclosed."

The Treasury Department approach allows debtors and creditors to negotiate and decide how any restructuring would take place before funds are transferred. Even the details regarding collective action clauses would be "determined by the borrowers and lenders." There would be nothing for a judge to do in such a case but act as a "disinterested arbitrator." unnecessary cost. Consequently, this provision would be inconsistent with the SDRM.

The SDRM creates an elaborate framework within which claims and issues can be raised and settled. It does not reduce the sovereign restructuring process to limited ex ante negotiations. While collective action clauses can be helpful in guiding future decisions regarding restructuring, they cannot account for the "rich and textured facts" 167 of any particular case. This aspect of the framework is one of the SDRM's proudest achievements because it is this well-defined, wellestablished process (not outcome) that will prevent future economic crises.

\section{The Value AdDed By The Traditionalist APPROACH}

With a small degree of manipulation, the previous Part has demonstrated that the traditionalists' views are captured in the IMF's SDRM proposal. Perhaps it would be more accurate to say that the SDRM contemplates and addresses the concerns of traditionalists to a greater extent than the collective action clause proposals. The following questions remain, though: Will a bankruptcy scheme that contemplates traditionalist values assist sovereign nations in restructuring their debt? Perhaps, more importantly, is such a scheme workable? The answer to both questions is uncertain, but a further examination of traditionalist philosophy assists in demonstrating the value added by the SDRM approach.

${ }^{164}$ Baird, supra note 110, at 579 (emphasis added).

${ }^{165}$ Taylor, supra note 84.

${ }^{166}$ See supra text accompanying note 143 (discussing the role of the judge in a proceduralist framework).

${ }^{167}$ Baird, supra note 110, at 579. 
Central to the traditionalists' theory is the notion that bankruptcy is fundamentally a legal system of distribution. ${ }^{168}$ Bankruptcy law assumes (whether true or not) that a debtor cannot repay its creditors. This assumption contrasts with the underlying theory behind state collection law, which tends to focus on "debtor-versus-creditor" disputes. ${ }^{169}$ More frequently, disputes in bankruptcy are not debtorversus-creditor, but rather "creditor-versus-creditor." Based on the assumptions of bankruptcy law, there is not enough money to go around. Therefore, bankruptcy law by necessity distributes those limited assets among various creditors. Who gets paid and how much they get paid are policy considerations based on a variety of normative issues. Bankruptcy law cannot, therefore, be watered down to a simple debtor-versus-creditor analysis. Nevertheless, this analysis seems to be the only one involved in the collective action clause approach.

Although Professor Elizabeth Warren does not articulate all of the distributional goals sought to be protected by bankruptcy law, her brief description is sufficient for present purposes. The distribution of debtors' assets is determined based on a consideration of the following issues: relative ability to bear the costs of default, incentive effects on pre-bankruptcy transactions, similarities among creditors, and benefits to the bankruptcy estate. ${ }^{171}$

Moreover, Warren recognizes that, when Congress enacted the Bankruptcy Code, it was not solely concerned with the relationship of a debtor to its unpaid creditors. ${ }^{172}$ Accordingly, Warren believes that Congress sought to "'protect the investing public, protect jobs, and help save troubled businesses."173 At the time of its enactment, the Code contemplated concerns regarding the community impact of bankruptcy, as well as the public interest beyond the interests of the disputing parties. $^{174}$

${ }^{168}$ See Warren, supra note 114 , at 785 ("Distribution among creditors is not incidental to other concerns; it is the center of the bankruptcy scheme.").

${ }^{169}$ See id. (describing the different assumptions of bankruptcy law and state collection law and how each deals with the problem of creditors and debtors).

${ }^{170}$ Id.

${ }^{171}$ See id. at 791-92 (examining how the Bankruptcy Code seeks to establish creditor priority).

${ }^{172}$ See id. at 788 (reviewing some of Congress's considerations in drafting the Bankruptcy Code).

${ }_{173}$ Id. (quoting 124 CONG. Rec. 32,392 (1978) (statement of Rep. Edwards)).

${ }^{174}$ See id. ("Congressional comments on the Bankruptcy Code ... indicate clear recognition of the larger implications of a debtor's widespread default ...."). 
With these concerns in mind, proponents of collective action clauses raise problematic arguments because they tend to focus so much on the debtor-creditor controversy and thereby overlook the normative distributional goals inherent in any form of restructuring law. As stated above, the proponents of the SDRM recognize that the central concern of any reorganization approach should be to protect the "national ... prosperity" of the debtor nation in addition to asset values and creditors' rights. ${ }^{175}$ The "community impact of bankruptcy" ${ }^{\prime 176}$ that troubled Congress is magnified in a discussion of sovereign debt restructuring. Not a community, but a country, will be affected by the procedure implemented by the international community. Any procedure that focuses on the conflict between the debtor and the creditor will marginalize the interests of the "community" and potentially exacerbate the very problems that caused the sovereign to default in the first place. Sovereign debt is not analogous to corporate debt in form or scope. To address the problem of sovereign debt restructuring as contractual, rather than distributional, ignores these differences.

\section{CONCLUSION}

Sovereign debt restructuring is a problem that has been ignored for quite some time. The flexibility of sovereign financing and the availability of funds from intergovernmental organizations have minimized the severity of the problem. However, as markets grow more integrated and criticisms of bailouts increase, avoidance of this problem may no longer be possible.

The position of the United States government has temporarily pushed the SDRM off the table in favor of a contract-based solution. Going forward, as questions arise regarding both the details of implementation and the effectiveness of the contractual approach, it is important to consider the substantial disagreement surrounding the proper role that reorganization rules should play in the legal system. In particular, focus should be placed on the impact of reducing the importance of normative distributional goals in the sovereign debt restructuring context.

This debate does not revolve around semantics. There are substantive differences between the two proposals, differences that may goals).

${ }^{175}$ See supra note 154 and accompanying text (discussing the breadth of the SDRM's

Warren, supra note 114, at 788. 
be influenced by conflicting philosophies regarding bankruptcy law. Focusing too much on the debtor-versus-creditor conflict could potentially limit the overall effectiveness of any restructuring plan because it does not address the rich complexity of sovereign debt. 
